\title{
EUROPE AND CHRISTIANITY: FROM YESTERDAY TO TOMORROW
}

\author{
EUROPA I CHRZEŚCIJAŃSTWO: HISTORIA I PRZYSZŁOŚĆ
}

Marios Begzos

University of Athens, Greece, MBEGZos@THeOL.UOA.GR

Keywords: Christianity, Europe, identity, heritage

Słowa kluczowe: Chrześcijaństwo, Europa, tożsamość, dziedzictwo

Is Europe Christian or not? This was the question that dominated some time ago the intense discussion during the working-out of the European Constitution. Two were the contrasting standpoints, one affirmative and one negative, which in turn set off a lot of contending. The final outcome was a suppression of the whole issue as far as the constitutional document is concerned, and an indirect reference to the humanistic legacy of Europe; a reference incorporated within the preamble of the ultimate constitutional chart of the European Union - which, of course, is still in the voting process.

However, the question remains open. A possible answer that could be regarded as historically fair and intellectually acceptable for everyone is the one that argues that the identity of Europe is biblical, i.e., monotheistic, without being univocally Christian nor exclusively humanistic or Enlightened; the latter conceived either as agnostic or as antireligious. To such an answer suggested herein two negations and one affirmation can be discerned, which demands some further explanation concerning the issue in point.

\section{The Christian Identity of Europe}

The Christian identity of Europe is justified by the historically ample presence of Christian elements, and their intellectually imposing appearance throughout the centuries. Moreover, it should be noted that the origins of the European Union, both with regards to the so-called EEC (European Economic Community) and the previous Trust of Coal and Steel, were Christian-Democratic, meaning that the Christian parameter constitutes a permanent cast over the European idea; to the extent, indeed, that the oblivion of the former entails the undermining of the latter. There is no need for someone to invoke excessive evidence in order to confirm the Christian lineage of the European Union.

The objection against the Christian identity of Europe comes basically from two directions. One is the European humanistic legacy of Renaissance and the En1ightenment, and the other the non-Christian religious tradition of the two other versions of monotheism, i.e., Judaism and Islam. Both opposing parts argue that through a formal constitutional declaration of the Christian identity of Europe a false impression will be given: a one-sidedness according to which Europe becomes a closed 'Christian league', where all others, i.e., people diverging from Christianity and dissidents, non-religious and religious alike, risk being marginalized.

In order thus to find a real common denominator for a unified Europe its Christian identity is suppressed, since under the above described situation it is regarded more as a threat than as a promise. This objection of course is deemed fair, but at the same time it has to be criticized as immoderate. Rightly those opposing argue that Europe risks becoming a closed 'Christian league', since by the explicit exclusivity of the Christian identity indeed two inequities take place, one with regard to the past and one with regard to the present.

We forget that Europe's past during its medieval, premodern period has been imbued with the spring waters of Judaism and Islam, which transferred Neo-Platonic and Aristotelian philosophy to such a degree, that Roman Catholicism repeated through scholasticism the Islamic attempt of renewing theology under the leadership of Tomas Aquinas. No-one can ever speak of a united Europe by forgetting the contribution of the Jewish intelligentsia, as well as that of certain Arab thinkers, who facilitated the development of medieval Christian theology. 
Thus it is for reasons of historical justice with regard to the European past that we have to mention the two other monotheistic traditions along with the Christian legacy, which obviously has the lead in the formation of Europe, but never monopolizes the creation of European culture. To be sure, Christianity retains precedence, but never had played an exclusive role in the formation of the European identity diachronically.

An inequity takes place against the historical present of the European Union when the two other versions of monotheism are suppressed, and Christianity is presented as monopolizing the European identity; for ín such a way the ample and seminal presence of labor migrants - basically from Muslim nations - is suppressed. How are Muslim migrants, living by the millions in Europe for many decades now, supposed to feel at home, when the Christian identity is declared as an exclusive feature of Europe and not just as a parameter of priority?

Moreover, slowly but steadily a discrimination slips into against European Jews, who are still bearing the historical trauma of the Holocaust, which was effected by Christian hands or, in any case, with the tolerance of the Christian authorities at the time, despite the indisputable participation of many a Christian from all Churches and denominations in the resistance movement against totalitarianism, and their opposition to concentration camps. The Christian identity of Europe seems to exclude every other religious legacy, which like the Jewish one has contributed to the integration of European culture both in its medieval past and its modem present; a fact that justifies historically the claim of all parts involved to have their share in the building of Europe acknowledged.

The point is neither the suppression of the Christian identity of Europe, nor the monopolizing of such a characteristic, so that instead of the true representation of what stands as a priority a false impression is given with regards to the exclusivity of Christianity in the building of the European Union. How could such a Gordian knot be cut, and which could possibly be its Solomonic resolution? As we shall see further on, the biblical identity of Europe does propose an answer to the problem in question.

The humanistic part wishes the total obliteration of any reference whatsoever to the Christian identity of Europe, for it recalls in horror the religious wars that tormented Europe (Reformation and Counter-Reformation), and well as today's various religious disputes extending form the northernmost point of Europe (Ireland) to its southernmost limit (the Balkans). The mentioning of Christianity within the European Constitution feeds a certain phobia, i.e., that the old religious disputes might be set off again, whereas the suppression of Christianity stimulates the humanistic reflexes of the Enlightenment, confirming in practice the principles of tolerance, forbearance, and religious freedom, not only at this or that national level but also at the transnational level of the European Union.

The humanistic objection to the declaration of the Christian identity of Europe seems justified, but it has to be judged as immoderate. The suppression of a historical entity such as Christianity does not entail its obliteration from history itself. Europe may not be called Christian, but historically and intellectually is imbued with the biblical - monotheistic legacy, while Christianity constitutes a great part of this biblical tradition. 'Evil' is not expelled via magic such as suppression, but is eliminated via drastic ways such as the substitution of biblical identity for Christian identity; an issue that leads us to the exploration of the monotheistic legacy of Europe, to which we turn in the following part of our paper.

\section{The Monotheistíc Identity of Europe}

After two negations, the non-Christian and the humanistic one, we can move on to our positive proposal as follows. The identity of Europe is biblical. The whole issue pertains to the Bible as the basis of the faith of the three versions of monotheism throughout history that penetrate Europe.

Monotheism resembles a triptych - Judaism, Christianity, and Islam - that acknowledges Abraham as the Patńarch of faith, and is based on the Bible. These three versions of monotheism are differentiated from one another with regards to many essential points, but converge in their faith to the One and Only God (monotheism), who is regarded as a personal existence with a male contour and fatherly attributes. Moreover, each version of monotheism is set forth in a holy text, i.e., the Hebrew Bible, the Holy Bible, and the Koran, each of them acknowledging the others to a certain degree, so that the sacredness of the foundational text of faith is retained as the common ground of all three versions of monotheism.

Europe is not Christian but biblical, that is, monotheistic. It is not exclusively Christian, since both Judaism and Islam have contributed to its formation in the past and still affect its making nowadays either via labor migrants or via non-Christian Europeans who have been living there for centuries. The Christian identity of Europe is acknowledged basically as historical and demographic, but by no means can it be accepted as a supposed exclusivity, neither of course as some kind of superiority. Christianity is biblical and in this sense it constitutes a component of Europe. In other words, it is 'biblical-ness' that constitutes the criterion of 'Christian-ness', and not vice versa. 
The same is valid for the other two versions of monotheism as well, since they contribute to the formation of Europe to the extent that they are rooted in the Bible, that is, have their own sacred texts in relation to the Bible. The Hebrew Bible is contained within the Christian Holy Bible as its Old Testament part, while the Koran acknowledges concussively the faithful of the Bible (Christians and Jews), exempting them from compulsory islamization. The acceptance of the Bible on the part of all three versions of monotheism is a sufficient and at the same time necessary condition, in order to include them into a single monotheistic legacy, which has contributed to the molding of Europe.

The humanistic suppression of the biblical identity of Europe would be a fatal mistake, for the vision of freedom as the fundamental emancipatory postulate of Europe is included within the Bible thanks to the exemplar of Exodus and the ideal of 'passing' (Pesah, Easter) from bondage to freedom. Enlightenment might have secularized the emancipation ideals of the Bible, but it has not been capable of denying their monotheistic origins. The reproach by secularized humanists against the versions of monotheism is precisely this, that these religious traditions have forgotten the best part of themselves, and have struck the flag of emancipation by suppressing the fact that the God of the Bible is the God of freedom, as it is clearly declared already at the beginning of the Decalogue.
Any reference to the Christian identity of Europe would be a good chance to underpin such emancipation ideals, and to strengthen them further through the mentioning of their biblical origins, so that the Enlightenment ideal of freedom can be better and more thoroughly promoted. The mentioning of the Christianidentity ofEuropemight seem slight, but the reference to its biblical identity is bright; insomuch as it is necessary in order to keep on inspiring our fellow humans í $\alpha$ the present and the future.

The biblical identity of Europe satisfies the demand for historical fairness with regard to the description of the development of Europe, while at the same time it justifies the monotheistic reality that sustains the European reality, not only in the past but also in the present. With regard to the future we can discern clearly enough the fact that the Bible endows Europe with unexpected dynamism, and promises a common future much more fertile and dynamic than the more distant or closer to us past.

No-one and nothing suffers damage or injustice by the reminder of the biblical identity of Europe. Non-Christian monotheists and non-religious humanists have the possibility to recognize the best part of themselves in the declaration of the biblical identity of Europe. It is in this sense that we believe that Europe is biblical, and with such an identity it has all the ease and freedom needed to proclaim its faith in a future that is synonymous to the freedom and humanity of man. 